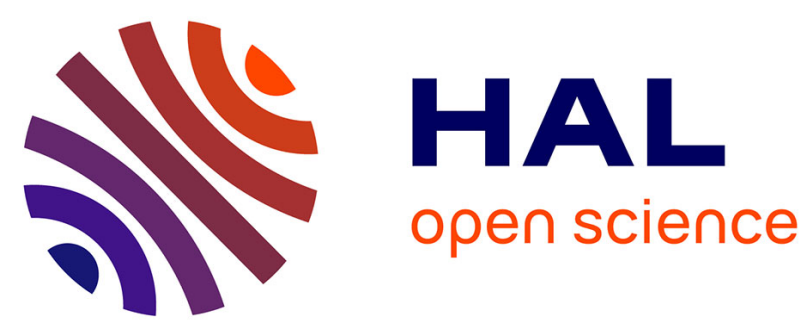

\title{
Relayed Proton Brake in N-Pyridyl-2-iso-propylaniline Derivative: Two Brakes with One Proton
}

Gaku Furukawa, Takeshi Shirai, Yuki Homma, Elsa Caytan, Nicolas Vanthuyne, Daniel Farran, Christian Roussel, Osamu Kitagawa

\section{To cite this version:}

Gaku Furukawa, Takeshi Shirai, Yuki Homma, Elsa Caytan, Nicolas Vanthuyne, et al.. Relayed Proton Brake in N-Pyridyl-2-iso-propylaniline Derivative: Two Brakes with One Proton. Journal of Organic Chemistry, 2020, 85 (7), pp.5109-5113. 10.1021/acs.joc.0c00284 . hal-02562367

HAL Id: hal-02562367 https://hal-univ-rennes1.archives-ouvertes.fr/hal-02562367

Submitted on 12 May 2020

HAL is a multi-disciplinary open access archive for the deposit and dissemination of scientific research documents, whether they are published or not. The documents may come from teaching and research institutions in France or abroad, or from public or private research centers.
L'archive ouverte pluridisciplinaire HAL, est destinée au dépôt et à la diffusion de documents scientifiques de niveau recherche, publiés ou non, émanant des établissements d'enseignement et de recherche français ou étrangers, des laboratoires publics ou privés. 


\title{
Relayed Proton Brake in N-Pyridyl-2-iso-propylaniline
}

\section{Derivative: Two Brakes with One Proton}

\author{
Gaku Furukawa ${ }^{\dagger}$, Takeshi Shirai ${ }^{\dagger}$, Yuki Homma ${ }^{\dagger}$, Elsa Caytan ${ }^{*+}$, Nicolas Vanthuyne $^{\S}$, Daniel Farran ${ }^{\S}$, \\ Christian Roussel ${ }^{*}$ and Osamu Kitagawa*t \\ †Department of Applied Chemistry (Japanese Association of Bio-intelligence for Well-being), Shibaura \\ Institute of Technology, 3-7-5 Toyosu, Kohto-ku, Tokyo, 135-8548, Japan. \\ Institut des Sciences Chimiques de Rennes, 35000, Rennes, France \\ §Aix Marseille Université, Centrale Marseille, CNRS, iSm2 UMR 7313, 13397 Cedex 20, Marseille, \\ France. \\ ${ }^{\dagger}$ E-mail: kitagawa@shibaura-it.ac.jp \\ E-mail : elsa.caytan@univ-rennes1.fr \\ §E-mail: christian.roussel@univ-amu.fr
}

\section{RECEIVED DATE}

TOC graphics

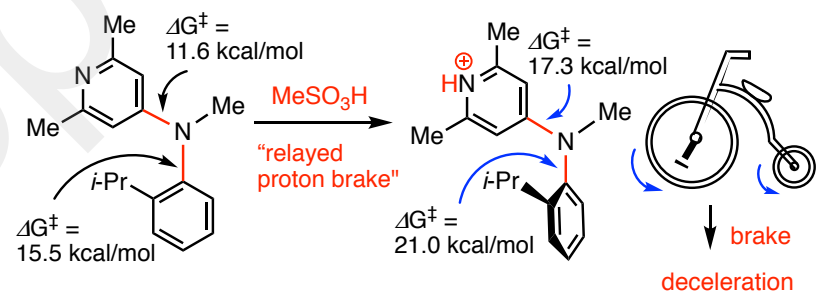

\begin{abstract}
The addition of methane sulfonic acid to $N$-(2,6-dimethylpyridin-4-yl)- $N$-methyl-2-isopropylaniline led to the selective protonation of the pyridine nitrogen atom, resulting in a significant deceleration of the rotation rates around both $\mathrm{N}$-pyridyl and $\mathrm{N}-(i$-Pr)phenyl bonds through a relayed brake mechanism.
\end{abstract}


Molecular rotors, which can control the rate and direction of bond rotation by external stimuli, have received much attention in the field of molecular device. ${ }^{1}$ Molecular brakes are one of the most fascinating classes of the molecular rotors, and the deceleration of a bond rotation has been achieved by a various external stimuli such as metal cations, acids, bases, halide anions, light and heat. ${ }^{2}$ On the other hand, as far as we know, molecular brake involving the rotational deceleration of plural bonds upon a single protonation has so far not been reported.

Recently we found that in N-C axially chiral 2-tert-butyl-6-methylanilines I bearing various parasubstituted phenyl groups on nitrogen atom, the rotational barriers around a chiral axis increase with electron-withdrawing ability of para-substituents X (Figure 1). ${ }^{3}$ Furthermore, on the basis of these results, a new type of molecular brake (remote proton brake) was developed. ${ }^{3,4}$ That is, the addition of methane sulfonic acid to $\mathrm{N}$-(4-aminophenyl)-2-iso-propylaniline II selectively protonated the primary amino group (the conversion of the electron-donating amino group into the electron-attracting ammonium group) to bring about a considerable increase in the rotational barrier around $\mathrm{N}-(i-\mathrm{Pr}) \mathrm{Ph}$ bond $(4 \mathrm{kcal} / \mathrm{mol})$. This brake thus resulted from a remote structural change at the $\operatorname{Ar}\left[\left(4-\mathrm{NH}_{2}\right) \mathrm{Ph}\right]$ group but not at the rotating $\operatorname{Ar}[\mathrm{N}-(i-\mathrm{Pr}) \mathrm{Ph}]$ group.
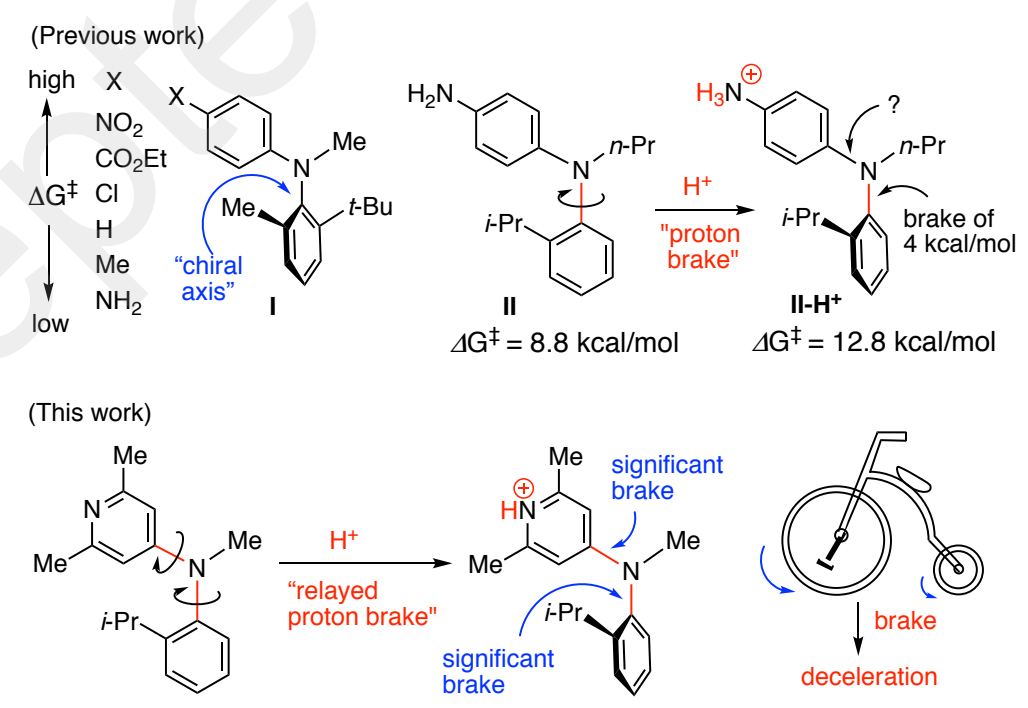

Figure 1. Correlation between the rotational barriers and the electronic effects in $\mathrm{N}-\mathrm{C}$ axially chiral anilines, and the application to proton brakes. 
In this paper, we report the effect of protonation on the stereodynamics of $\mathrm{N}$-methyl-2-isopropylanilines bearing a 2- or 4-pyridyl group on the nitrogen atom. It was revealed that aniline having a 4-pyridyl group leads to the more considerable brake than 2-pyridyl derivative upon protonation. Furthermore, in 4-pyridyl derivative, a double brake phenomenon, where the rotations around two N-Ar bonds are synchronously decelerated under a single protonation (relayed proton brake), was found.

In line with our previous findings in aniline derivatives I and II, we envisioned that $\mathrm{N}$-pyridyl-2iso-propylaniline derivatives would also lead to proton brake around $\mathrm{N}-(i-\mathrm{Pr}) \mathrm{Ph}$ bond through the selective protonation of the remote basic pyridine nitrogen. In addition, the strong electron-withdrawing character of the pyridyl group was expected to produce measurable rotational barriers around both the $\mathrm{N}$-pyridyl and $\mathrm{N}-(i-\mathrm{Pr}) \mathrm{Ph}$ bonds allowing the experimental determination of barriers about two N-Ar bonds in the neutral and protonated states. Although the synthesis of $N$-(4-pyridyl)-2-iso-propylaniline was initially attempted, the coupling reaction of 2-iso-propylaniline with 4-halopyridine did not efficiently proceed. ${ }^{5}$ On the other hand, Buchwald-Hartwig amination of iso-propylaniline with 2bromopyridine or 4-bromo-2,6-dimethylpyridine proceeded smoothly, ${ }^{6}$ and subsequent $N$-methylation gave the desired $N$-methyl- $N$-pyridyl-2-iso-propylanilines $\mathbf{1}$ and $\mathbf{2}$ in good yields (Scheme 1).

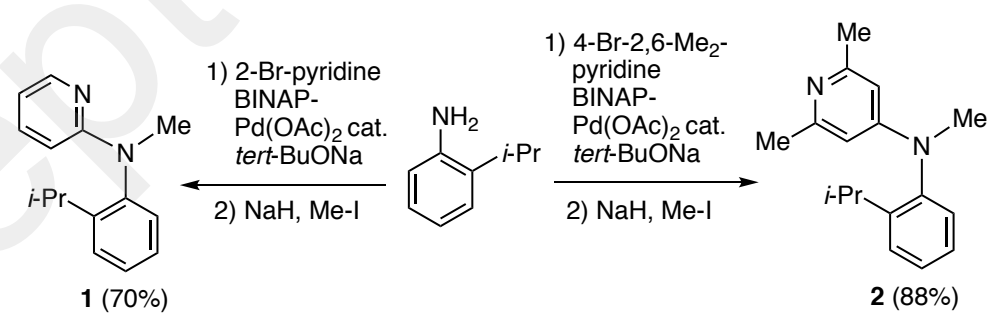

Scheme 1. Synthesis of $N$-methyl- $N$-pyridyl-2-iso-propylaniline derivatives 1 and $\mathbf{2}$.

At room temperature, the ${ }^{1} \mathrm{H}-\mathrm{NMR}$ peak corresponding to the two Me hydrogens of isopropyl group in 2-pyridyl aniline 1 was broadened (Figure 2). When $\mathrm{MeSO}_{3} \mathrm{H}$ (1.0 equiv) was added to 1 in toluene- $\mathrm{d}_{8}$, the broad signal was splitted into two doublet signals. The non- 
equivalency of two Me signals revealed an axial chirality owing to the rotational restriction around $\mathrm{N}-(i-\mathrm{Pr}) \mathrm{Ph}$ bond at the time scale of $\mathrm{NMR}$ in $\mathbf{1 - \mathbf { H } ^ { + }}$.

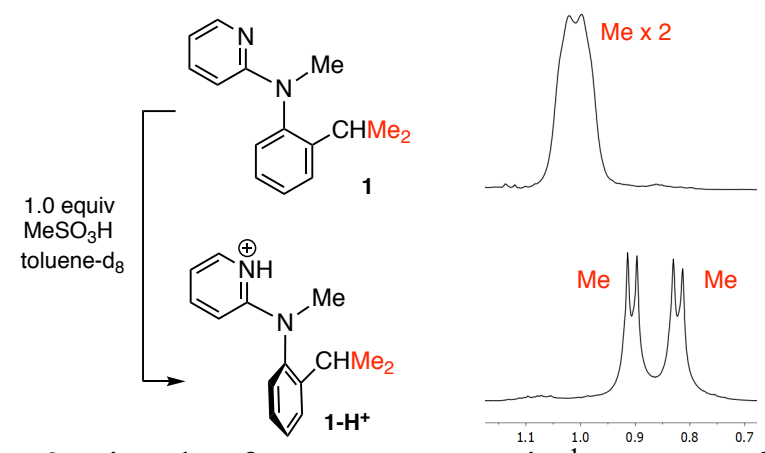

Figure 2. Signals of two Me groups in ${ }^{1} \mathrm{H}-\mathrm{NMR}$ of $\mathbf{1}$ and $\mathbf{1 - \mathbf { H } ^ { + }}$ at $\mathbf{r t}$.

Variable temperature NMR (VT-NMR) experiments of $\mathbf{1}$ and $\mathbf{1 - \mathbf { H } ^ { + }}$ were further conducted for the evaluation of the rotational barriers (Figure 3). In aniline 1, the broad Me signal of $i$-Pr at $295 \mathrm{~K}$ was changed into a sharp doublet signal indicating quick $\mathrm{N}-(i-\mathrm{Pr}) \mathrm{Ph}$ bond rotation around $330 \mathrm{~K}$, while it splitted into two doublet signals revealing an axial chirality around $280 \mathrm{~K}$. In pyridinium derivative 1$\mathbf{H}^{+}$, non-equivalent two Me signals at $295 \mathrm{~K}$ were coalesced around $350 \mathrm{~K}$. On the basis of the VTNMR charts and the line shape simulation with WinDNMR,${ }^{7}$ the rotational barriers around $\mathrm{N}-(i-\mathrm{Pr}) \mathrm{Ph}$ bond in $\mathbf{1}$ and $\mathbf{1}-\mathbf{H}^{+}$were evaluated to be 15.1 and $17.2 \mathrm{kcal} / \mathrm{mol}$, respectively. Although the rotational barriers of $\mathbf{1}$ and $\mathbf{1 - \mathbf { H } ^ { + }}$ bearing electron-withdrawing 2-pyridyl and 2-pyridinium groups were much higher than those of 4-aminophenyl derivatives $\mathbf{I I}$ and $\mathbf{I I - H ^ { + }}(8.8$ and $12.8 \mathrm{kcal} / \mathrm{mol})$, the magnitude of proton brake in $\mathbf{1}(2.1 \mathrm{kcal} / \mathrm{mol})$ decreased in comparison with that of II $(4.0 \mathrm{kcal} / \mathrm{mol})$. 


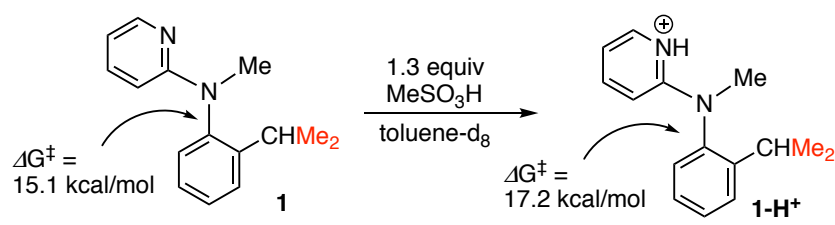

In (2,6-dimethylpyridin-4-yl)-2-iso-propylaniline 2, two hydrogens (and two Me groups) on pyridine ring and two Me groups of iso-Pr in aniline $\mathbf{2}$ showed equivalent NMR signals at $\mathrm{rt}$ in toluene$\mathrm{d}_{8}$, while the addition of $\mathrm{MeSO}_{3} \mathrm{H}$ (1.3 equiv) to 2 resulted in the formation of non-equivalent hydrogen signals (Figure 4). The non-equivalency of pyridinium hydrogens and $i$-Pr Me groups should be due to the rotational restriction around $\mathrm{N}-$ pyridinium bond and $\mathrm{N}-(i-\mathrm{Pr}) \mathrm{Ph}$ bond, respectively. ${ }^{8}$ Especially, for two hydrogens on pyridininium ring, a significant difference of the chemical shift was observed $(\Delta \delta=$ $1.15 \mathrm{ppm})$. This may indicate that pyridinium ring and iso-Pr-phenyl ring in $\mathbf{2}-\mathbf{H}^{+}$are co-planar and perpendicular, respectively, toward the nitrogen plane $\left[\mathrm{Me}-\mathrm{N}-\mathrm{C}_{4}(\mathrm{Py})-\mathrm{C}_{1}(i-\mathrm{Pr}) \mathrm{Ph}\right.$ plane]. It results that the two hydrogens ( $\mathrm{Hb}: \delta=5.45 \mathrm{ppm}$, Ha: $\delta=6.50 \mathrm{ppm})$ on pyridinium ring are located inside and outside of the iso-Pr-phenyl ring cone, respectively. In proton free 2, since the rotation around Npyridyl bond frequently occurs, the two hydrogens on the pyridine gave a single signal at average chemical shift (ca. 6.0 ppm) between $\mathrm{Ha}$ and $\mathrm{Hb}$. 

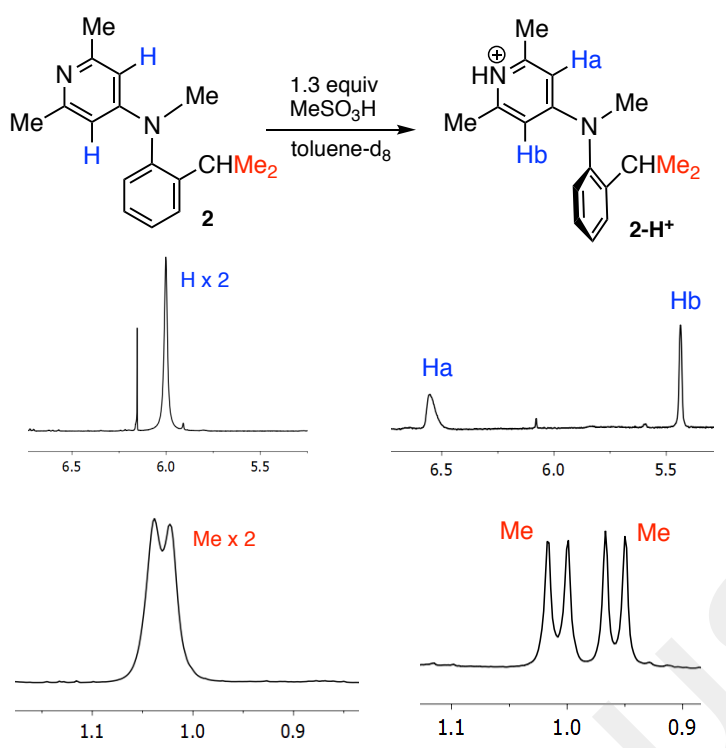

Figure 4. ${ }^{1} \mathrm{H}-\mathrm{NMR}$ signals of $\mathbf{2}$ and $\mathbf{2}-\mathbf{H}^{+}$in toluene- $\mathrm{d}_{8}$ at $\mathrm{rt}$.

VT-NMR experiment of $\mathbf{2}$ and $\mathbf{2}-\mathbf{H}^{+}$and the line-shape simulation were subsequently performed (Figure 5). In aniline 2 in toluene- $\mathrm{d}_{8}$, equivalent hydrogens of pyridine ring and $i$-Pr group at $300 \mathrm{~K}$ were changed to non-equivalent hydrogens around $240 \mathrm{~K}$ and $270 \mathrm{~K}$, respectively, and the rotational barriers around $\mathrm{N}$-pyridyl and $\mathrm{N}-(i-\mathrm{Pr}) \mathrm{Ph}$ bonds were evaluated to be 11.6 and $15.5 \mathrm{kcal} / \mathrm{mol}$, respectively. The barrier about $\mathrm{N}-(i-\mathrm{Pr}) \mathrm{Ph}$ bond in 4-pyridyl derivative $\mathbf{2}$ is similar to that in 2-pyridyl derivative $1(15.1 \mathrm{kcal} / \mathrm{mol})$.

For non-equivalent hydrogens of pyridinium ring and $i$-Pr group in $\mathbf{2}-\mathbf{H}^{+}$, the broadening and sharpening of NMR signals were observed, respectively, with increasing temperature, while two Me signals of $i$-Pr were slightly broadened at $370 \mathrm{~K} .{ }^{9}$ Full coalescence of these non-equivalent signals was not attained even at $370 \mathrm{~K}$ (limited heating temperature of toluene- $\mathrm{d}_{8}$ ), indicating high rotational barriers for these N-Ar bonds. Nevertheless, the rotational barrier of the N-pyridinium bond in $\mathbf{2}-\mathbf{H}^{+}$was evaluated to be $17.3 \mathrm{kcal} / \mathrm{mol}$ through the line-shape simulation, and this value was $5.7 \mathrm{kcal} / \mathrm{mol}$ higher than that in 2 . The $5.7 \mathrm{kcal} / \mathrm{mol}$ corresponds to the neat proton brake affecting the pyridine motif rotation on going from $\mathbf{2}$ to $\mathbf{2}-\mathbf{H}^{+}$. For $\mathrm{N}-(i-\mathrm{Pr}) \mathrm{Ph}$ bond in $\mathbf{2}-\mathbf{H}^{+}$, the rotational barrier could be evaluated 
by the line-shape simulation of the doublet signal at the limit temperature $(370 \mathrm{~K})$. The rotational barrier was revealed to be $21.0 \mathrm{kcal} / \mathrm{mol}$ which is $5.5 \mathrm{kcal} / \mathrm{mol}$ higher than that in 2 . This value $(5.5 \mathrm{kcal} / \mathrm{mol})$ corresponds to the neat relayed brake affecting the $\mathrm{N}-(i-\mathrm{Pr}) \mathrm{Ph}$ bond rotation on going from $\mathbf{2}$ to $\mathbf{2}-\mathbf{H}^{+}$. It is noteworthy that the magnitude of proton brake around $\mathrm{N}-(i-\mathrm{Pr}) \mathrm{Ph}$ bond in 4-pyridyl derivative 2 (5.5 $\mathrm{kcal} / \mathrm{mol})$ is considerably larger than that in 2-pyridyl derivative $\mathbf{1}(2.1 \mathrm{kcal} / \mathrm{mol})$, while the reason is unclear at the present time.

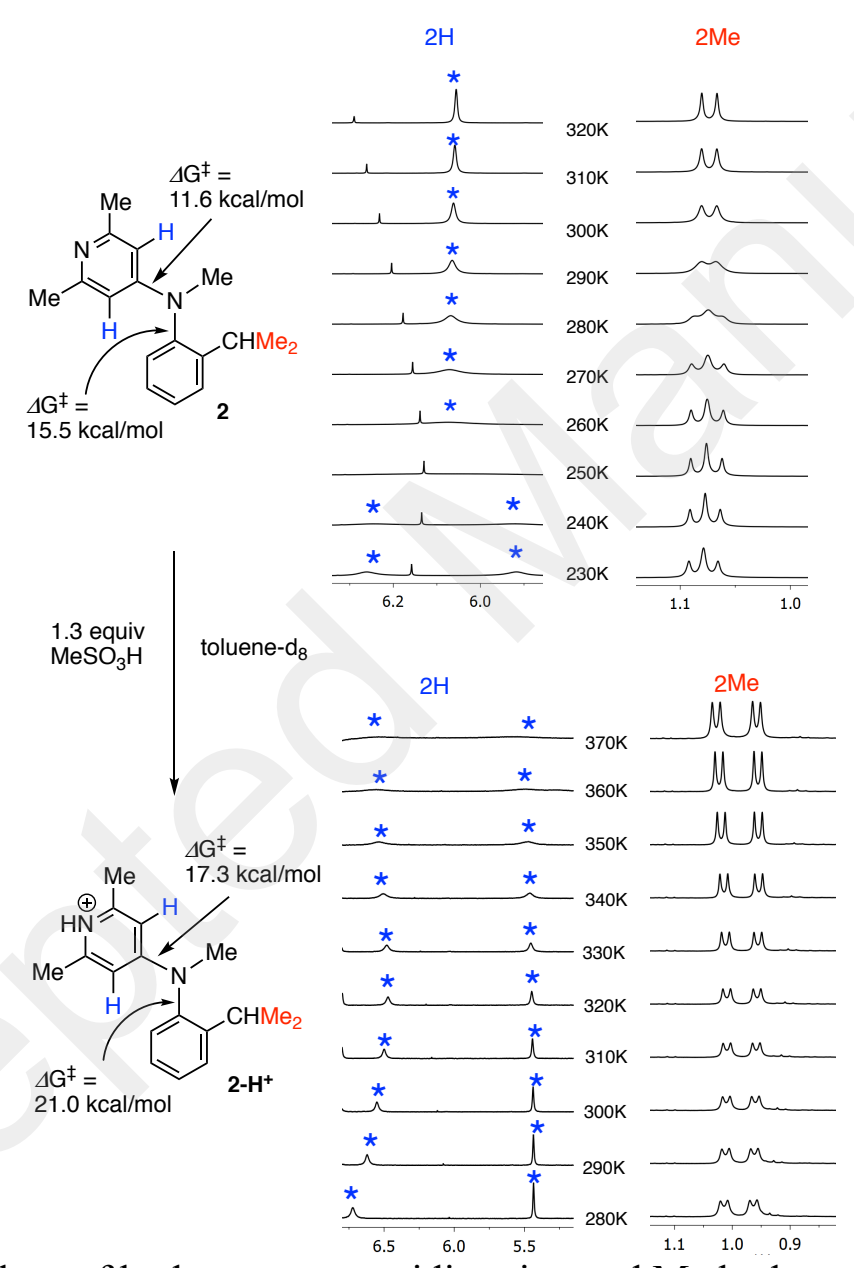

Figure 5. VT-NMR chart of hydrogens on pyridine ring and Me hydrogens in $\mathbf{2}$ and $\mathbf{2}-\mathbf{H}^{+}$in toluene-d 8.

VT-NMR measurement of $\mathbf{2}$ and $\mathbf{2}-\mathbf{H}^{+}$in DMSO- $\mathrm{d}_{6}$ followed by the line-shape simulation were also performed. The high melting point of DMSO- $\mathrm{d}_{6}$ did not allow the determination of the barrier for the $\mathrm{N}$-pyridine bond in 2 but the three other barriers around $\mathrm{N}-(i$ - $\mathrm{Pr}) \mathrm{Ph}\left(\Delta \mathrm{G}^{\ddagger}=15.3 \mathrm{kcal} / \mathrm{mol}\right)$ bond in $\mathbf{2}, \mathrm{N}$ - 
pyridinium bond $\left(\Delta \mathrm{G}^{*}=17.2 \mathrm{kcal} / \mathrm{mol}\right)$ in $\mathbf{2}-\mathrm{H}^{+}$and $\mathrm{N}-(i-\mathrm{Pr}) \mathrm{Ph}$ bond $\left(\Delta \mathrm{G}^{*}=21.4 \mathrm{kcal} / \mathrm{mol}\right)$ in $\mathbf{2}-\mathbf{H}^{+}$ were nicely evaluated thank to the higher range of attainable temperatures. They all were very slightly higher $(0.4 \mathrm{kcal} / \mathrm{mol})$ than those determined in toluene- $\mathrm{d}_{8}$ revealing a very weak solvent effect (see SI). Furthermore, the similarity of the barriers in a weakly dissociating solvent such as toluene- $\mathrm{d}_{8}$ and a strongly dissociating solvent such as DMSO- $\mathrm{d}_{6}$ clearly shows that the barriers evolve from the same molecular entities in the two solvents. A conjectural contribution of ion pairs or H-bonded complexes in barrier determination for $\mathbf{2}-\mathbf{H}^{+}$in toluene- $\mathrm{d}_{8}$ can be ruled out. In summary, going from $\mathbf{2}$ to $\mathbf{2}-\mathbf{H}^{+}$, the rotation rates around two $\mathrm{N}-\mathrm{C}$ axes are considerably decelerated by a single protonation.

The significant double brakes observed in 4-pyridyl derivative $\mathbf{2}$ may be rationalized in accordance with Figure 6. The addition of $\mathrm{MeSO}_{3} \mathrm{H}$ to 2 leads to a selective protonation of the pyridine nitrogen to generate $\mathbf{2}-\mathbf{H}^{+}$. In $\mathbf{2}-\mathbf{H}^{+}$, the double bond character about an $\mathrm{N}$-pyridinium bond is increased by strong resonance of the lone electron pair on tert-amino group with pyridinium ring, leading to the significant increase in the rotational barrier. The rotational brake around N-pyridinium bond also remarkably influences the rotation around an $\mathrm{N}-(i-\mathrm{Pr}) \mathrm{Ph}$ bond. We previously reported the rotational mechanism around N-Ar bond in $\mathrm{N}$-(4-aminophenyl)-2-substituted-anilines based on DFT calculation. ${ }^{3}$ It indicates that in the transition state during N-Ar(2-substituted-phenyl) bond rotation, 4-aminophenyl group is largely twisted because of the alleviation of the steric repulsion with an ortho-substituent on 2substituted-phenyl group. Similarly, the twisting of pyridyl group would be required for $\mathrm{N}-(i-\mathrm{Pr}) \mathrm{Ph}$ bond rotation in $\mathbf{2}$ and $\mathbf{2}-\mathbf{H}^{+}$. The energy for the twisting of pyridinium group in $\mathbf{2}-\mathbf{H}^{+}$should be higher than that of pyridyl group in $\mathbf{2}$ due to the increase in the double bond character of $\mathrm{N}$-pyridinium bond in $\mathbf{2 - \mathbf { H } ^ { + }}$. As a result, the rotational barrier around $\mathrm{N}-(i-\mathrm{Pr}) \mathrm{Ph}$ bond in $\mathbf{2}-\mathbf{H}^{+}$is significantly increased. In such interlocking controlled rotational mechanism, the change in rotational barriers around $\mathrm{N}-(i-\mathrm{Pr}) \mathrm{Ph}$ bond may be determined by the change in barrier for N-pyridyl bond rotation. Namely, the proton brake 
in $\mathrm{N}-(i-\mathrm{Pr}) \mathrm{Ph}$ and $\mathrm{N}$-pyridyl bonds would possess a similar magnitude. Indeed, the brake magnitude of $\mathrm{N}-(i-\mathrm{Pr}) \mathrm{Ph}$ bond $(5.5 \mathrm{kcal} / \mathrm{mol})$ was very close to that of $\mathrm{N}-$ pyridyl bond $(5.7 \mathrm{kcal} / \mathrm{mol})$.
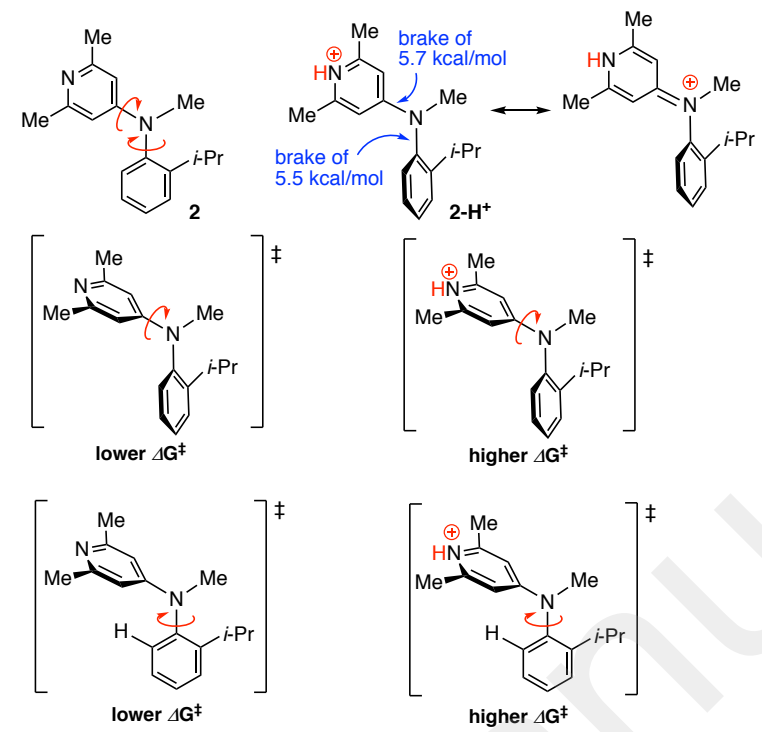

Figure 6. Transition state model for the N-Ar bond rotation in $\mathbf{2}$ and $\mathbf{2}-\mathbf{H}^{+}$.

\section{CONCLUSION}

We succeeded in the development of proton brake molecules through the protonation of $N$-methyl2-iso-propylanilines bearing a 2- or 4-pyridyl group on the nitrogen atom. The brake magnitude in 4pyridyl derivative was more considerable than that of 2-pyridyl derivative. Furthermore, in 4-pyridyl derivative, it was found that the rotation rates around two N-Ar bonds are remarkably decelerated by a single protonation. The deceleration of two N-Ar bond rotations proceeds via a relayed mechanism in which the brake of an N-Ar (N-pyridyl) bond also causes the brake of an another $\mathrm{N}-\mathrm{Ar}[\mathrm{N}-(i-\mathrm{Pr}) \mathrm{Ph}]$ bond. ${ }^{10}$ To the best of our knowledge, this work is the first example on communicating molecular brakes. This brake system is similar to that of a penny farthing bike in which the rotational speeds of two wheels having different size (different rotational barriers) are synchronously decreased by a single front brake (Figure 1). ${ }^{11}$ 


\section{EXPERIMENTAL SECTION}

${ }^{1} \mathrm{H}$ and ${ }^{13} \mathrm{C}$ NMR spectra were recorded on a $400 \mathrm{MHz}$ spectrometer. In ${ }^{1} \mathrm{H}$ and ${ }^{13} \mathrm{C}$ NMR spectra, chemical shifts were expressed in $\delta(\mathrm{ppm})$ downfield from $\mathrm{CHCl}_{3}(7.26 \mathrm{ppm})$ and $\mathrm{CDCl}_{3}(77.0 \mathrm{ppm})$, respectively. HRMS were recorded on a double focusing magnetic sector mass spectrometer using electron impact ionization. Column chromatography was performed on silica gel (75-150 mm).

$\boldsymbol{N}$-Methyl- $\boldsymbol{N}$-(2-pyridyl)-2-iso-propylaniline (1). Under $\mathrm{N}_{2}$ atmosphere, $\mathrm{Pd}(\mathrm{OAc})_{2}$ (9 mg, $\left.0.04 \mathrm{mmol}\right)$ and rac-BINAP $(50 \mathrm{mg}, 0.08 \mathrm{mmol})$ in toluene $(0.5 \mathrm{~mL})$ were stirred for $10 \mathrm{~min}$ at rt. 2-isoPropylaniline $(135 \mathrm{mg}, 1.0 \mathrm{mmol})$ in toluene $(1.5 \mathrm{~mL}), t$-BuONa $(144 \mathrm{mg}, 1.5 \mathrm{mmol})$ and 2bromopyridine ( $98 \mu \mathrm{L}, 1.0 \mathrm{mmol})$ were added to the reaction mixture, and the mixture was stirred for 3 $\mathrm{h}$ at $80{ }^{\circ} \mathrm{C}$ (oil bath). The mixture was poured into saturated aqueous $\mathrm{NH}_{4} \mathrm{Cl}$ solution and extracted with AcOEt. The AcOEt extracts were washed with brine, dried over $\mathrm{Na}_{2} \mathrm{SO}_{4}$, and evaporated to dryness. Purification of the residue by column chromatography (hexane/AcOEt $=10)$ gave $N$-(2-pyridyl)-2-isopropylaniline (172 mg). Under $\mathrm{N}_{2}$ atmosphere, to $\mathrm{NaH}(60 \%$ assay, $65 \mathrm{mg}, 1.6 \mathrm{mmol})$ in 1,4-dioxane $(2.0 \mathrm{~mL})$ were added $N$-(2-pyridyl)-2-iso-propylaniline $(172 \mathrm{mg}, 0.8 \mathrm{mmol})$ and iodomethane $(76 \mu \mathrm{L}$, $1.2 \mathrm{mmol}$ ), and then the mixture was stirred for $24 \mathrm{~h}$ at $80^{\circ} \mathrm{C}$ (oil bath). The mixture was poured into saturated aqueous $\mathrm{NH}_{4} \mathrm{Cl}$ solution and extracted with AcOEt. The AcOEt extracts were washed with brine, dried over $\mathrm{Na}_{2} \mathrm{SO}_{4}$, and evaporated to dryness. Purification of the residue by column chromatography $(\mathrm{AcOEt} / \mathrm{MeOH}=4)$ gave 1 (159 mg, 70\%). 1: colorless oil; IR (neat) $2963 \mathrm{~cm}^{-1} ;{ }^{1} \mathrm{H}$ NMR (400 MHz, $\left.\mathrm{CDCl}_{3}\right) \delta: 8.21(1 \mathrm{H}, \mathrm{dt}, J=5.0,1.0 \mathrm{~Hz}), 7.42(1 \mathrm{H}, \mathrm{dd}, J=7.8,1.8 \mathrm{~Hz}), 7.34(1 \mathrm{H}, \mathrm{td}, J$ = 7.6, $1.4 \mathrm{~Hz}), 7.22-7.28(2 \mathrm{H}, \mathrm{m}), 7.13(1 \mathrm{H}, \mathrm{dd}, J=7.8,1.4 \mathrm{~Hz}), 6.55(1 \mathrm{H}, \mathrm{ddd}, J=7.8,5.0,0.9 \mathrm{~Hz})$, $6.02(1 \mathrm{H}, \mathrm{d}, J=8.7 \mathrm{~Hz}), 3.38(3 \mathrm{H}, \mathrm{s}), 3.04(1 \mathrm{H}, \mathrm{sept}, J=6.8 \mathrm{~Hz}), 1.15(6 \mathrm{H}, \mathrm{brd}) ;{ }^{13} \mathrm{C}\left\{{ }^{1} \mathrm{H}\right\} \mathrm{NMR}(100$ $\left.\mathrm{MHz}, \mathrm{CDCl}_{3}\right) \delta: 159.1,147.6,147.5,143.5,136.5,128.8,127.9,127.6,127.3,112.0,108.2,38.3,27.6$ 24.2, 23.6; MS (m/z) $227\left(\mathrm{MH}^{+}\right)$; HRMS (ESI) $m / z$ : $[\mathrm{M}+\mathrm{H}]^{+}$calcd for $\mathrm{C}_{15} \mathrm{H}_{19} \mathrm{~N}_{2}$ 227.1548; found: 227.1560. 
$\boldsymbol{N}$-Methyl- $\boldsymbol{N}$-(2,6-dimethylpyridin-4-yl)-2-iso-propylaniline (2). Under $\mathrm{N}_{2}$ atmosphere, $\operatorname{Pd}(\mathrm{OAc})_{2}(9$ $\mathrm{mg}, 0.04 \mathrm{mmol})$ and $\mathrm{rac}$-BINAP $(50 \mathrm{mg}, 0.08 \mathrm{mmol})$ in toluene $(0.5 \mathrm{~mL})$ were stirred for $10 \mathrm{~min}$ at $\mathrm{rt}$. 2-iso-Propylaniline $(135 \mathrm{mg}, 1.0 \mathrm{mmol})$ in toluene $(1.0 \mathrm{~mL}), t$-BuONa $(144 \mathrm{mg}, 1.5 \mathrm{mmol})$ and 4bromo-2,6-dimethylpyridine $(186 \mathrm{mg}, 1.0 \mathrm{mmol})$ in toluene $(1.0 \mathrm{~mL})$ were added to the reaction mixture, and the mixture was stirred for $3 \mathrm{~h}$ at $110^{\circ} \mathrm{C}$ (oil bath). The mixture was poured into saturated aqueous $\mathrm{NaHCO}_{3}$ solution and extracted with AcOEt. The AcOEt extracts were washed with brine, dried over $\mathrm{Na}_{2} \mathrm{SO}_{4}$, and evaporated to dryness. Purification of the residue by column chromatography $(\mathrm{AcOEt} / \mathrm{MeOH}=4)$ gave $N$-(2,6-dimethylpyridin-4-yl)-2-iso-propylaniline $(240 \mathrm{mg})$. Under $\mathrm{N}_{2}$ atmosphere, to $\mathrm{NaH}(60 \%$ assay, $65 \mathrm{mg}, 1.6 \mathrm{mmol})$ in DMF $(2.0 \mathrm{~mL})$ were added $\mathrm{N}-(2,6-$ dimethylpyridin-4-yl)-2-iso-propylaniline (240 mg, $1.0 \mathrm{mmol})$ and iodomethane $(75 \mu \mathrm{L}, 1.2 \mathrm{mmol})$, and then the mixture was stirred for $24 \mathrm{~h}$ at $\mathrm{rt}$. The mixture was poured into saturated aqueous $\mathrm{NaHCO}_{3}$ solution and extracted with AcOEt. The AcOEt extracts were washed with brine, dried over $\mathrm{Na}_{2} \mathrm{SO}_{4}$, and evaporated to dryness. Purification of the residue by column chromatography $(\mathrm{AcOEt} / \mathrm{MeOH}=4)$ gave 2 (224 mg, 88\%). 2: colorless oil; IR (neat) $2961 \mathrm{~cm}^{-1} ;{ }^{1} \mathrm{H}$ NMR (400 MHz, CDCl $) \delta: 7.42(1 \mathrm{H}$, $\mathrm{dd}, J=7.8,1.8 \mathrm{~Hz}), 7.36(1 \mathrm{H}, \mathrm{td}, J=7.4,1.1 \mathrm{~Hz}), 7.27(1 \mathrm{H}, \mathrm{td}, J=7.4,1.6 \mathrm{~Hz}), 7.05(1 \mathrm{H}, \mathrm{dd}, J=7.8$, $0.9 \mathrm{~Hz}), 6.03(2 \mathrm{H}, \mathrm{brs}), 3.22(3 \mathrm{H}, \mathrm{s}), 2.89(1 \mathrm{H}, \mathrm{sept}, J=6.8 \mathrm{~Hz}), 2.37(6 \mathrm{H}, \mathrm{s}), 1.14(3 \mathrm{H}, \mathrm{d}, J=6.4 \mathrm{~Hz})$, $1.10(3 \mathrm{H}, \mathrm{d}, J=6.8 \mathrm{~Hz}) ;{ }^{13} \mathrm{C}\left\{{ }^{1} \mathrm{H}\right\} \mathrm{NMR}\left(100 \mathrm{MHz}, \mathrm{CDCl}_{3}\right) \delta: 157.3,152.2,147.2,143.3,128.4,128.1$, 127.5, 127.3, 103.8, 39.2, 27.7, 24.5, 24.3, 23.4; MS (m/z) $277\left(\mathrm{MNa}^{+}\right)$; HRMS (ESI) $m / z:[\mathrm{M}+\mathrm{Na}]^{+}$ calcd for $\mathrm{C}_{17} \mathrm{H}_{22} \mathrm{~N}_{2} \mathrm{Na} 277.1681$; found, 277.1677.

$\boldsymbol{N}$-Methyl- $\boldsymbol{N}$-(2-pyridinium)-2-iso-propylaniline methane sulfonate $\left(\mathbf{1 - \mathbf { H } ^ { + }}\right) . \quad$ To $\mathbf{1}$ in $\mathrm{CDCl}_{3}$ was added 1.3 equivalent of $\mathrm{MeSO}_{3} \mathrm{H}$ and the ${ }^{1} \mathrm{H}-\mathrm{NMR}$ was measured at rt. $\mathbf{1 - \mathbf { H } ^ { + }}{ }^{1} \mathrm{H} \mathrm{NMR}(400 \mathrm{MHz}$, $\left.\mathrm{CDCl}_{3}\right) \delta: 8.46(1 \mathrm{H}, \mathrm{t}, J=5.5 \mathrm{~Hz}), 7.63(1 \mathrm{H}, \mathrm{t}, J=7.8 \mathrm{~Hz}), 7.45-7.51(2 \mathrm{H}, \mathrm{m}), 7.35(1 \mathrm{H}, \mathrm{m}), 7.10(1 \mathrm{H}$, d, $J=7.8 \mathrm{~Hz}), 6.86(1 \mathrm{H}, \mathrm{t}, J=6.4 \mathrm{~Hz}), 6.31(1 \mathrm{H}, \mathrm{d}, J=8.7 \mathrm{~Hz}), 3.65(3 \mathrm{H}, \mathrm{s}), 2.92(3 \mathrm{H}, \mathrm{s}), 2.79(1 \mathrm{H}$, sept, $J=6.8 \mathrm{~Hz}), 1.23(3 \mathrm{H}, \mathrm{d}, J=6.9 \mathrm{~Hz}), 1.11(3 \mathrm{H}, \mathrm{d}, J=6.9 \mathrm{~Hz}) .{ }^{13} \mathrm{C}\left\{{ }^{1} \mathrm{H}\right\} \mathrm{NMR}\left(100 \mathrm{MHz}, \mathrm{CDCl}_{3}\right)$ $\delta: 152.8,146.0,142.6,139.3,137.9,130.3,128.6,128.3,127.3,112.6,40.6,39.3,28.0,24.1,23.6$. 


\section{$N$-Methyl- $N$-(2,6-dimethylpyridinium-4-yl)-2-iso-propylaniline methane sulfonate (2-H ${ }^{+}$). To 1} in $\mathrm{CDCl}_{3}$ was added 1.2 equivalent of $\mathrm{MeSO}_{3} \mathrm{H}$ and the ${ }^{1} \mathrm{H}-\mathrm{NMR}$ was measured at rt. ${ }^{1} \mathrm{H}$ NMR (400

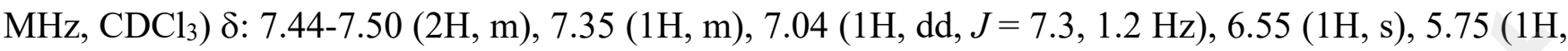
s), $3.38(3 \mathrm{H}, \mathrm{s}), 3.22(3 \mathrm{H}, \mathrm{s}), 2.90(3 \mathrm{H}, \mathrm{s}), 2.73(1 \mathrm{H}, \mathrm{m}), 2.46(3 \mathrm{H}, \mathrm{s}), 1.22(3 \mathrm{H}, \mathrm{d}, J=6.7 \mathrm{~Hz}), 1.11(3 \mathrm{H}$, $\mathrm{d}, J=6.7 \mathrm{~Hz}) .{ }^{13} \mathrm{C}\left\{{ }^{1} \mathrm{H}\right\} \mathrm{NMR}\left(100 \mathrm{MHz}, \mathrm{CDCl}_{3}\right) \delta: 158.0,152.7,151.0,145.8,140.5,129.9,128.4$, $128.1,127.1,106.3,103.7,40.3,39.5,28.0,24.2,23.6,19.9,19.4$.

\section{AUTHOR INFORMATION}

\section{Corresponding Authors}

Osamu Kitagawa, E-mail: kitagawa@shibaura-it.ac.jp

Elsa Caytan, E-mail : elsa.caytan@univ-rennes1.fr

Christian Roussel, E-mail: christian.roussel@univ-amu.fr

\section{ORCID}

Osamu Kitagawa 0000-0001-7964-1879

Elsa Caytan 0000-0003-0490-3074

Christian Roussel 0000-0003-1377-7081

Daniel Farran 0000-0003-4687-7871

Nicolas Vanthuyne 0000-0003-2598-7940

\section{Notes}

The authors declare no competing financial interest.

\section{SUPPORTING INFORMATION}

The Supporting Information is available free of charge on the ACS Publications website at DOI: 
Copies of ${ }^{1} \mathrm{H}$ and ${ }^{13} \mathrm{C}$-NMR spectra, VT-NMR data and the determination of the rotational barriers in $\mathbf{1}, \mathbf{2}, \mathbf{1}-\mathbf{H}^{+}, \mathbf{2}-\mathbf{H}^{+}$.

\section{ACKNOWLEDGMENT}

This work was partly supported by JSPS KAKENNHI (C 17K08220).

\section{REFERENCES}

1. Typical papers on molecular rotors: (a) Iwamura, H.; Mislow, K. Stereochemical Consequences of Dynamic Gearing. Acc. Chem. Res. 1988, 21, 175. (b) Kelly, T. R.; Silva, H.; Silva, R. Unidirectional Rotary Motion in a Molecular System. Nature 1999, 401, 150. (c) Koumura, N.; Zijlstra, R. W. J.; van Delden, R. A.; Harada, N.; Feringa, B. L. Light-driven Monodirectional Molecular Rotor. Nature 1999, 401, 152. (d) Kottas, G. S.; Clarke, L. I.; Horinek, D.; Michl, J. Artificial Molecular Rotors. Chem. Rev. 2005, 105, 1281. (e) Coskun, A.; Banaszak, M.; Astumian, R. D.; Stoddart, J. F.; Grzybowski, B. A. Great Expectations: Can Artificial Molecular Machines Deliver on Their Promise? Chem. Soc. Rev. 2012, 41, 19.

2. Typical papers on molecular brake: (a) Kelly, T. R.; Bowyer, M. C.; Bhaskar, K. V.; Bebbington, D.; Garcia, A.; Lang, F.; Kim, M. H.; Jette, M. P. A Molecular Brake. J. Am. Chem. Soc. 1994, 116, 3657. (b) Takeuchi, M.; Imada, T.; Shinkai, S. A Strong Positive Allosteric Effect in the Molecular Recognition of Dicarboxylic Acids by a Cerium(IV) Bis[tetrakis(4pyridyl)porphyrinate] Double Decker. Angew. Chem. Int. Ed. 1998, 37, 2096. (c) Jog, P.; Brown, R.; Bates, D. A Redox-Mediated Molecular Brake: Dynamic NMR Study of 2-[2(Methylthio)phenyl]isoindolin-1-one and S-Oxidized Counterparts. J. Org. Chem. 2003, 68, 8240. (d) Harrington, L. E.; Cahill, L. S.; McGlinchey, M. J. Toward an Organometallic Molecular Brake with a Metal Foot Pedal: Synthesis, Dynamic Behavior, and X-ray Crystal Structure of [(9-Indenyl)triptycene]chromium Tricarbonyl. Organometallics, 2004, 12, 2884. (e) 
Yang, J.; Huang, Y.; Ho, J.; Sun, W.; Huang, H.; Lin, Y.; Huang, H.; Huang, S.; Lu, H.; Chao, I. A Pentiptycene-Derived Light-Driven Molecular Brake. Org. Lett. 2008, 11, 2279. (f) Hirose, K.; Ishibashi, K.; Shiba, H.; Doi, Y.; Tobe, Y. Highly Effective and Reversible Control of the Rocking Rates of Rotaxanes by Changes to the Size of Stimulus-Responsive Ring Components. Chem. Eur. J. 2008, 14, 5803. (g) Basheer, M. C.; Oka, Y.; Mathews, M.; Tamaoki, N. A LightControlled Molecular Brake with Complete ON-OFF Rotation. Chem. Eur. J. 2010, 16, 3489.

3. Iwasaki, Y.; Morisawa, R.; Yokojima, S.; Hasegawa, H.; Roussel, C.; Vanthuyne, N.; Caytan, E.; Kitagawa, O. N-C Axially Chiral Anilines: Electronic Effect on Barrier to Rotation and A Remote Proton Brake. Chem. Eur. J. 2018, 24, 4453.

4. Typical papers on molecular rotors based on the control of N-C bond rotation: (a) Dial, B. E.; Rasberry, R. D.; Bullock, B. N.; Smith, M. D.; Pellechia, P. J.; Profeta, S, Jr.; Shimizu, K. D. Guest-Accelerated Molecular Rotor. Org. Lett. 2011, 13, 244. (b) Dial, B. E.; Pellechia, P. J.; Smith, M. D.; Shimizu, K. D. Proton Grease: An Acid Accelerated Molecular Rotor. J. Am. Chem. Soc. 2012, 134, 3675. (c) Wu, Y.; Wang, G.; Li, Q.; Xiang, J.; Jiang, H.; Wang, Y. A multistage rotational speed changing molecular rotor regulated by $\mathrm{pH}$ and metal cations. Nat. Commun. 2018, 9, 1953.

5. Although the aromatic nucleophilic substitution of 2-iso-propylaniline with 4-bromo-pyridine hydrochloride gave the desired $N$-(4-pyridyl)-2-iso-propylaniline, the chemical yield was poor.

6. (a) Guram, A. S.; Rennels, R. A.; Buchwald, S. L. A Simple Catalytic Method for the Conversion of Aryl Bromides to Arylamines. Angew. Chem. Int. Ed. Engl. 1995, 34, 1348. (b) Hartwig, J. F.; Loue, J. Palladium-catalyzed synthesis of arylamines from aryl halides. Mechanistic studies lead to coupling in the absence of tin reagents. Tetrahedron Lett. 1995, 36, 3609. 
7. (a) C. Wolf, Dynamic Stereochemistry of Chiral Compounds: Principles and Applications, RSC Publishing: Cambridge, 2008. (b) Clayden, J.; Fletcher, S. P.; McDouall, J. J. W.; Rowbottom, S. J. M. Controlling Axial Conformation in 2-Arylpyridines and 1-Arylisoquinolines: Application to the Asymmetric Synthesis of QUINAP by Dynamic Thermodynamic Resolution. J. Am. Chem. Soc. 2009, 131, 5331.

8. Although the rotational brake around $\mathrm{N}$-pyridinium bond in $\mathbf{1}-\mathbf{H}^{+}$may also occur, it was difficult to detect in the 2-pyridyl substrates having no equivalent hydrogens such as 4-pyridyl derivative 2-H' $\mathbf{H}^{+}$On the other hand, in 4-aminophenyl derivative II, the non-equivalency of hydrogens on 4-aminophenyl ring was not observed through the addition of $\mathrm{MeSO}_{3} \mathrm{H}$ because of the low rotational barrier around $\mathrm{N}-\left(4-\mathrm{NH}_{3}{ }^{+} \mathrm{Ph}\right)$ bond.

9. The broadened signals of Me groups at low temperature may result from the physical state of the solution.

10. One may augur that the oxidation or methylation at the pyridine nitrogen in $\mathbf{2}$ to yield the corresponding N-oxide or N-methyl-pyridinium salt would also produce a strong deceleration of the rotation rates. These chemical transformations which do not comply with the reversibility requirement in molecular motor brake were not further considered.

11. A reviewer suggested that bevel gear bearing two orthogonal rotors is more appropriate than the penny farthing bike as a mechanical analogy. This is right in terms of topology but the gear analogy is somewhat misleading for our two blade molecular machine. The penny farthing bike is another example in which two interdependent rotating systems with different rotation rates can be simultaneously affected by a single brake. 